\title{
Bahasa Isyarat Dalam Memahami Bacaan Shalat Pada Anak- anak Tunarungu
}

\author{
Damar Retno Dhyanti ${ }^{{ }^{*}}$, Jujun Junaedi ${ }^{1}$, Tata Sukayat ${ }^{2}$ \\ 1,2Jurusan Komunikasi dan Penyiaran Islam, Fakultas Dakwah dan Komunikasi, UIN Sunan \\ Gunung Djati, Bandung \\ *Email : damarretnodbyanti@gmail.com
}

\begin{abstract}
ABSTRAK
Penyandang tunarungu memiliki hambatan pendengaran dan dalam proses bicara dan bahasanya terhambat pula. Penyandang tunarungu menggunakan bahasa isyarat sehari-hari dalam berkomunikasi dengan orang lain. Materi yang diajarkan pun menggunakan bahasa isyarat oleh guru mereka. Materi pelajaran yang biasanya disampaikan lewat bahasa lisan, harus disampaikan lewat bahasa isyarat. Termasuk juga pelajaran agama Islam yang disampaikan oleh bahasa isyarat, seperti bacaan shalat yang disampaikan dengan bahasa isyarat di SLB Negeri Cileunyi. Tujuan penelitian ini untuk mengetahui perhatian, pemahaman dan penerimaan anak-anak tunarungu terhadap bahasa isyarat dalam memahami bacaan shalat. Serta mengenal bahasa isyarat sebagai komunikasi nonverbal. Jenis penelitian ini adalah kuantitatif dengan metode deskriptif. Teknik yang digunakan dalam pengumpulan data diantaranya yaitu observasi, angket dan wawancara. Terdapat respon antara bahasa isyarat yang digunakan anak-anak tunarungu dengan bacaan shalat yang diajarkan di sekolah. Bahasa isyarat membantu anak-anak tunarungu dalam memahami, mengikuti serta pada pengaplikasian bacaan shalat di sekolah maupun di rumah.
\end{abstract}

Kata Kunci : Anak-anak Tunarungu; Bahasa Isyarat; Bacaan Shalat

\section{ABSTRACT}

Deaf people have hearing impairments and are also hampered in the process of speech and language. Deaf people use daily sign language in communicating with others. The material tanght also uses sign language by their teacher. The subject matter, which is usually delivered through oral language, must be delivered through sign language. It also includes Islamic lessons delivered by sign language, such as prayer readings delivered in sign language at SLB Negeri 
Cileunyi. The purpose of this study was to determine the attention, understanding and acceptance of deaf children to sign language in understanding prayer readings. And recognize sign language as nonverbal communication. This type of research is quantitative with descriptive methods. Techniques used in data collection include observation, questionnaires and interviews. There is a response between sign language used by deaf children and prayer readings taught at school. Sign language helps deaf children understand, follow along with the application of prayer readings at school or at home.

Keywords : Deaf Children; Sign language; Prayer Readings

\section{PENDAHULUAN}

Komunikasi dapat dikategorikan menjadi dua, yaitu komunikasi verbal dan nonverbal. Komunikasi verbal merupakan komunikasi yang biasa dilakukan secara lisan maupun tulisan, sedangkan nonverbal merupakan komunikasi yang menggunakan isyarat, gerak tubuh serta mimik wajah dalam proses komunikasinya. Sederhananya, komunikasi nonverbal merupakan semua isyarat yang bukan kata-kata.

Komunikasi adalah suatu faktor yang penting bagi perkembangan hidup manusia sebagai makhluk sosial. Tanpa mengadakan komunikasi, manusia tidak mungkin dapat berkembang dengan normal dalam lingkungan sosialnya, karena tak ada manusia yang hidup berkembang tanpa berkomunikasi dengan manusia lainnya (Mubasyaroh, 2017:311).

Dalam hal ini yang akan menjadi fokus yaitu peran bahasa isyarat sebagai komunikasi nonverbal bagi anak-anak tuna rungu pada kemampuan memahami bacaan sholat di SLBN Cileunyi. Bahasa isyarat merupakan bahasa yang mengutamakan komunikasi manual, bahasa tubuh, dan gerak bibir untuk berkomunkasi. Penyandang tunarungu merupakan kelompok utama yang menggunakan bahasa ini, biasanya mengkombinasikan bentuk tangan, orientasi dan gerak tangan, lengan dan tubuh, serta ekspresi wajah untuk mengungkapkan pikiran mereka.

Penyandang tunarungu memiliki hambatan pendengaran dalam proses bicara dan bahasanya terhambat pula, disebabkan oleh hambatan pendengarannya. Sebagai akibat dari terhambatnya perkembangan bicara dan bahasanya, akan mengalami kelambatan dan kesulitan dalam hal-hal yang berhubungan dengan komunikasi. Menggunakan bahasa isyarat merupakan langkah yang diambil oleh mereka yang memiliki kekurangan bicara atau 
mendengar untuk tetap mampu berinteraksi dengan masyarakat umum (Prasetyo, 2014).

Komunikasi yang dilakukan oleh guru dalam hal ini sangat penting untuk menjelaskan mengenai bacaan sholat dan Al-Quran kepada siswa atau siswi penyandang tuna rungu. Hal ini merupakan dakwah yang dilakukan oleh guru kepada siswa-siswanya terlepas dari tugasnya sebagai pengajar. Dakwah yang dilakukan oleh guru di SLBN Cileunyi merupakan dakwah fi'ah qalilah.

Di SLBN Cileunyi, satu kelas dapat berisikan tiga sampai lima orang siswa dengan satu pengajar. Setiap kelas mempunyai guru khusus masing-masing. Kegiatan dialog antara guru dan siswa-siswa tuna rungu di SLBN Cileunyi dapat di kategorikan sebagai dakwah fi'ah.

Sholat merupakan kewajiban setiap muslim. Dalam hal ini, bahasa isyarat diperlukan sebagai sarana komunikasi untuk menjelaskan tentang bacaan sholat pada siswa. Untuk gerakan sholatnya dapat dilakukan dengan tubuh, tetapi untuk bacaannya agak sulit untuk menghafal surat-surat pendek pun sepertinya agak sulit. Maka bahasa isyarat berperan sebagai komunikasi nonverbal yang digunakan guru pada siswa untuk menjelaskan tentang bacaan sholat di SLBN Cileunyi.

Penelitian terdahulu yang menjadi acuan dalam penggarapan skripsi penulis, untuk tema yang sama dengan topik yang berbeda. Skripsi milik Hafizha Rizqa Febrina, Mahasiswi Universitas Islam Negeri Sunan Kalijaga Yogyakarta, program studi Ilmu Komunikasi. Skripsi ini berjudul "PENGGUNAAN BAHASA ISYARAT SEBAGAI KOMUNIKASI (Atudi Efektifitas Komunikasi Non Verbal dan Non Vokal Pada Siaran Berita TVRI Nasional Terhadap Penyandang Tunarungu SLB PGRI Minggir, Sleman, Yogyakarta)".

Kesimpulan yang dapat diambil yaitu penggunaan bahasa isyarat sebagai komunikasi dinilai memiliki hasil yang efektif. Tujuan dari penelitian ini untuk mengetahui efektivitas penggunaan bahasa isyarat sebagai komunikasi dalam siaran berita di TVRI pada penyandang tunarungu di SLB PGRI Minggir, Sleman, Yogyakarta tercapai. Hal ini juga disebabkan oleh media TVRI yang merupakan satu-satunya media yang menanyangkan berita dengan menggunakan bahasa isyarat.

Perbedaannya dengan penelitian ini, yaitu terdapat pada pengaplikasian bahasa isyarat. Pada penelitian sebelumnya bahasa isyarat digunakan dalam program siaran berita yang di tayangkan di TVRI pada penyandang tunarungu. Penyandang tunarungu memiliki hak yang sama dalam menerima informasi. Maka dari itu stasiun televisi, bijaknya memberikan bahasa isyarat untuk 
penyandang tunarungu. Agar mereka dapat menerima serta menikmati program tayangan televisi. Pengaplikasian bahasa isyarat dalam penelitian ini terdapat pada pelajaran bacaan shalat yang dilakukan oleh guru SLBN Cileunyi. Bahasa isyarat tidak hanya dari gerak tubuh saja, melainkan melalui gerak bibir juga yang dapat dibaca oleh anak-anak tunarungu. Bacaan shalat merupakan bacaan yang biasanya diajarkan melalui lisan. Maka perlu ada pengulangan dalam belajar bacaan shalat terutama untuk anak-anak tunarungu. Perbedaannya terletak juga pada media yang digunakan, jika penelitian terdahulu menggunakan media elektronik dalam penyampaian bahasa isyarat yang disiarkan dalam program berita, jika di SLBN Cileunyi media lisan dan langsung disampaikan melalui guru yang mengajar di kelas.

SLB Negeri Cileunyi terletak di Jalan Pandawangi Cibiru Indah III Cibiru Wetan-Cileunyi Kabupaten Bandung, Kode pos 40625. Lokasi penelitian dilakukan di SLB Negeri Cileunyi. Jl. Pandawangi Cibiru III Cileunyi Kabupaten Bandung karena lokasi penelitian strategis.

Ada tiga hal yang di bahas dalam jurnal ini, yaitu mengenai perhatian anak anak tuna rungu di SLB Negeri Cileunyi dalam memahami bacaan sholat menggunakan bahasa isyarat, pemahaman untuk bacaan sholat menggunakan bahasa isyarat di SLBN Cileunyi pada anak-anak tuna rungu serta kendala yang dihadapi dan hasil penerimaan anak-anak tunarungu di SLB Negeri Cileunyi dalam memahami bacaan sholat menggunakan bahasa isyarat.

Pada penelitian ini, penulis menggunakan metode kuantitatif. Metode kuantitatif yaitu metode penyajian data dalam bentuk jumlah atau angka yang dituangkan untuk menerangkan suatu kejelasan dari angka-angka atau memperbandingkan dari beberapa gambaran sehingga memperoleh gambarangambaran baru, kemudian dijelaskan kembali dalam kalimat atau diurakan.

Untuk pengumpulan data menggunakan beberapa teknik yaitu, teknik observasi, wawancara dan kuesioner. Dalam observasi atau pengamatan ini dilakukan secara langsung, dengan cara mengamati langsung terhadap komunikasi yang dilakukan guru terhadap siswa siswi penyandang tunarungu dalam menjelaskan mengenai kemampuan pemahaman bacaan sholat di SLBN Cileunyi.

Penelitian menggunakan teknik wawancara ini bertujuan untuk mendapatkan data atau informasi lebih lanjut tentang pengenalan,proses dan hasil dari bahasa isyarat yang digunakan sebagai pembelajaran dalam kemampuan pemahaman bacaan sholat di SLBN Cileunyi dari narasumber dengan melakukan tanya jawab secara langsung. Wawancara ini dilakukan terhadap pengajar di 
SLBN Cileunyi. Angket yang dipakai pada penelitian ini yaitu berupa beberapa pertanyaan yang terkait dengan perhatian, pemahaman dan penerimaan siswa siswi tuna rungu dalam memahami bacaan sholat. Terdapat sepuluh responden yang mengisi kuesioner. Mulai dari tingkat pendidikan sekolah dasar hingga sekolah menengah keatas.

Kemudian untuk menghitung persentase jawaban responden dalam bentuk tabel tunggal melalui distribusi frekuensi dan persentase. Dengan menggunakan rumus:

\section{LANDASAN TEORITIS}

Dakwah yaitu mengajak manusia kepada jalan Allah (sistem Islam) secara menyeluruh, baik dengan lisan maupun tulisan, maupun dengan perbuatan untuk mewujudkan nilai-nilai ajaran Islam dalam kehidupan pribadi, keluarga dan masyarakat (Enjang, 2009:5)

Dalam hal ini, bahasa isyarat dalam menjelaskan bacaan sholat yang dilakukan oleh guru kepada muridnya termasuk kedalam dakwah. Karena terdapat banyak nilai-nilai kebaikan seperti pada penjelsan di atas. Dakwah yang dilakukan guru pada siswa siswi tuna rungu di SLB Negeri Cipadung, dapat dikategorikan sebagai dakwah fi'ah.

Dakwah ini merupakan dakwah yang dilakukan seseorang terhadap kelompok kecil dalam suasana bertatap muka, bisa berdialog serta respon pendengar dapat diketahui seketika. Ciri dari dakwah ini yaitu berupa kelompok kecil dan dapat berlangsung secara tatap muka dan dialogis. (Aliyudin,2009:68)

Dakwah berasal dari bahasa Arab, dari akar kata da'a, yad'u, da'watan yang bermakna seruan, panggilan, undangan atau do'a. Jika dikaitkan dengan kata Islam, dakwah menjadi kegiatan mengajak, memanggil, menyeru seseorang kepada Islam. (Syamsuddin,2016:3). Dalam konteks pengertian bahasa Al-Quran terdapat pada surat An-Nahl 125:

125. Serulah (manusia) kepada jalan Tuhan-mu dengan hikmah dan pengajaran yang baik, dan berdebatlah mereka dengan cara yang baik. Sesungguhnya Tuhan-mu, Dialah yang lebih Mengetahui siapa yang sesat dari jalan-Nya dan Dialah yang lebih Mengetahui siapa yang mendapat petunjuk (Terjemah Al-Quran Departemen Agama RI hal. 281 tahun 2007).

Dalam teori respon, menggunakan Teori S-O-R. Teori S-O-R sebagai singkatan dari Stimulus-Organism-Response. Menurut teori ini, efek yang 
ditimbulkan adalah reaksi khusus terhadap stimulus khusus, sehingga seseorang dapat mengharapkan dan memperkirakan kesesuaian antara pesan dan reaksi komunikan.

Unsur-unsur dalam Teori S-O-R yaitu: Pesan (Stimulus, S); Komunikan (Organism, O); Efek (Response, R). Dalam proses perubahan sikap tampak bahwa sikap dapat berubah, hanya jika stimulus yang menerpa benar-benar melebihi semula. Pesan yang disampaikan pada komunikan mungkin akan diterima atau mungkin ditolak. Komunikasi akan berlangsung jika ada perhatian dari komunikan. Proses berikutnya komunikan mengerti. Kemampuan komunikasi inilah yang melanjutkan proses berikutnya. Setelah komunikan mengolahnya dan menerimanya, maka terjadilah kesediaan untuk mengubah sikap.

Komunikasi merupakan salah satu hal yang penting bagi manusia, hubungan manusia dengan manusia lainnya bergantung pada komunikasi yang digunakan, baik yang sudah kenal atau pun tidak kenal sama sekali. Komunikasi dapat dikategorikan menjadi dua, yaitu komunikasi verbal dan nonverbal. Komunikasi verbal merupakan komunikasi yang biasa dilakukan secara lisan maupun tulisan, sedangkan nonverbal merupakan komunikasi yang menggunakan isyarat, gerak tubuh serta mimik wajah dalam proses komunikasinya. Sederhananya, komunikasi nonverbal merupakan semua isyarat yang bukan kata-kata.

Banyak perilaku verbal bersifat tersirat dan diproses secara kognitif, perilaku nonverbal bersifat spontan, ambigu, sering berlangsung cepat dan diluar kesadaran dan kendali kita (Mulyana, 2014:344).

Komunikasi adalah peristiwa penyampaian ide manusia. Oleh karena itu dapat dikatakan bahwa komunikasi merupakan suatu proses penyampaian pesan yang dapat berupa pesan informasi, ide, emosi, keterampilan melalui simbol atau lambang yang dapat menimbulkan efek tertentu, baik tingkah laku yang dilakukan oleh media-media tertentu (Sihabudin, 2019: 63).

Komunikasi verbal dan nonverbal memiliki perbedaan, komunikasi nonverbal memiliki lebih banyak muatan emosional daripada komunikasi verbal karena lebih mengutamakan gerak tubuh atau simbol. Sementara kata-kata umumnya digunakan untuk menyampaikan fakta, pengetahuan, atau keadaan, pesan nonverbal lebih potensial untuk menyatakan perasaan seseorang, yang terdalam sekalipun, seperti rasa sayang atau sedih. (Mulyana,2014:349)

Fungsi-fungsi pesan nonverbal yaitu : Repetisi, mengulang kembali 
gagasan yang sudah disajikan secara verbal. Subtitusi, menggantikan lambanglambang verbal. Kontradiksi, menolak pesan verbal atau memberikan makna yang lain terhadap pesan verbal. Komplemen, melengkapi dan memperkaya makna pesan nonverbal. Aksentuasi, menegaskan pesan verbal atau menggaris bawahinya.( Rakhmat,2012:283).

Selanjutnya mengenai bahasa isyarat, menurut Kamus Besar Bahasa Indonesia (Badan Pengembangan dan Pembinaan Bahasa, 2016), bahasa isyarat merupakan bahasa yang tidak menggunakan bunyi ucapan manusia atau tulisan dalam sistem perlambanganya.

Dalam bahasa isyarat, kita dapat berkomunikasi mengginakan gerakan tangan, kepala, badan, dan lain-lain), bahasa ini khusu diciptakan untuk penyandang tuna rungu, tuna wicara, tuna netra, dan sebagainya untuk mempermudah komunikasi sehari-hari. Kebanyakan dari mereka yang menggunakan bahasa isyarat merupakan tuna rungu dan tuna wicara.

Bahasa isyarat memiliki keunikan tersendiri, pada tiap negara-terdapat bahasa isyarat yang berbeda-beda pula. Uniknya, kita dapat menggunakan anggota badan untuk menyampaikan suatu pesan pada lawan bicara. Bahasa isyarat tidak memiliki ruang lingkup pengguna yang besar, seperti bahasa lisan, sehingga tidak banyak orang yang mengerti dan paham bahasa isyarat yang disampaikan oleh lawan bicara. (Gunawan,2013:78)

Bahasa isyarat digunakan untuk berkomunikasi oleh penyandang tuna rungu dan wicara pada kegiatan sehari-hari. Bahasa isyarat dapat dipelajari di sekolah. Bahasa Isyarat salah satu cara berkomunikasi yang diambil, oleh mereka yang memiliki kekurangan berbicara dan mendengar agar dapat berinteraksi dengan masyarakat umum.

Selain oleh penyandang tuna rungu, bahasa isyarat dapat dipelajari oleh orang yang dapat mendengar agar dapat berkomunikasi dengan isyarat sederhana. Salah satu kesulitan yang dihadapi penyandang tuna tungu yaitu menginformasikan bahasa isyarat agar dapat dipahami oleh orang yang dapat mendengar, agar penyandang tuna rungu dapat berkomunikasi bergaul dan berinteraksi dalam kehidupan sehari-hari. (Maharoni dkk, 2018:2877)

Bahasa isyarat yang digunakan disekolah yaitu SIBI (Sistem Isyarat Bahasa Indonesia). SIBI ini merupakan salah satu media yang dapat membantu komunikasi sesama penyandang tunarungu dalam masyarakat yang lebih luas. SIBI berbentuk tatanan yang sistematis tentang isyarat jari, tangan dan berbagai gerak yang dapat melambangkan kosa kata dalam Bahasa Indonesia. (Maulia,2017:83). 
Tunarungu merupakan keadaan dimana seseorang mempunyai kelainan dalam pendengarannya sehingga memberikan dampak pada kemampuan berkomunikasi terutama kemampuan berbicara. Namun, penyandang tunarungu memiliki hak yang sama dalam berkomunikasi dan berbahasa seperti yang lainnya. Dalam berkomunikasi sehari-hari, penyandang tunarungu dapat berinteraksi menggunakan bahasa isyarat. (Winaldi,Setyawan,2018:70)

Tunarungu memiliki dua macam definisi sesuat dengan tujuannya, pertama, definisi pada tujuan medis, ini berarti kekurangan atau kehilangan kemampuan untuk mendengar yang disebabkan oleh adanya kerusakan dan disfungsi sebagian atau seluruh alat-alat pendengaran. Kedua, definisi pedagogis, ini berarti kekurangan atau kehilangan pendengaran yang mengakibatkan terhambatnya perkembangan sehingga membutuhkan bimbingan khusus.

Selanjutnya, dalam mata pelajaran di sekolah terdapat pelajaran agama Islam. Mata pelajaran agama Islam, kebanyakan menggunakan lisan dalam mempelajarinya, karena terdapat materi doa sehari-hari maupun doa untuk bacaan shalat. Dalam hal ini dibutuhkan kesabaran dalam mengajar anak-anak tunarungu tentang bacaan shalat. Guru di SLBN Cileunyi, menggunakan gerak bibir yang dapat dibaca oleh anak-anak tunarungu dalam mempelajari bacaan shalat.

\section{HASIL DAN PEMBAHASAN}

Terdapat tiga indikator pada pembahasan ini, yaitu perhatian, pemahaman dan penerimaan. Pada aspek perhatian abak-anak tunarungu terhadap bahasa isyarat dalam memahami bacaan shalat, mendapat hasil presentase rata-rata sebesar $66 \%$. Perolehan ini dapat dilihat dari jawaban yang diberikan responden dari lima soal mengenai perhatian yang diberikan oleh peneliti.

Dapat juga dilihat bahwa sebagian besar anak-anak tunarungu mulai dari kelas 6 SD sampai kelas 12 SMA, memperhatikan dengan baik saat guru mengajar menggunakan bahasa isyarat. Bahasa yang dipakai untuk berkomunikasi di sekolah maupun di rumah. Sebagian besar anak-anak tunarungu dapat mengikuti pelajaran agama Islam menggunakan bahasa isyarat. Walaupun terdapat kendala seperti, materi pelajaran yang biasanya disampaikan dengan bahasa lisan, harus disampaikan dengan bahasa isyarat. Anak-anak tunarungu akan membaca gerak bibir dari guru yang mengajar. Maka guru yang mengajar harus memiliki pelafalan dan intonasi yang jelas, agar anak-anak tunarungu dapat memahami yang disampaikan oleh guru mereka. Pada aspek perhatian, sebagian besar anak-anak tunarungu dapat mengikuti bacaan shalat 
yang diajarkan oleh guru di sekolah. Bacaan shalat biasanya disampaikan oleh bahasa lisan, maka perlunya kesabaran serta keuletan guru dalam mengajar siswa siswi tunarungu.

Indikator kedua yaitu pemahaman, memperoleh hasil presentase rata-rata sebesar 64\%. Sebagian besar anak-anak tunarungu paham dengan bahasa isyarat dan dapat menggunakan bahasa isyarat dengan baik. Untuk berkomunikasi dengan guru dan teman-teman mereka, digunakan bahasa isyarat. Karena responden berusia mulai dari 11 tahun hingga 18 tahun, mereka sudah lumayan lancar dalam menggunakan bahasa isyarat. Dari segi pemahaman pelajaran agama Islam dan bacaan shalat, sebagian besar dapat memahaminya dengan baik.

Indikator ketiga yaitu Penerimaan, mendapat hasil presentase rata-rata sebanyak 70\%. Ini berarti pada indikator penerimaan, anak-anak tuanrungu dapat menerima bahasa isyarat dengan baik. Dari hasil angket, anak-anak tunarungu merasa bahasa isyarat membantu mereka dalam berkomunikasi seharihari dengan teman di sekolah. Bahasa isyarat juga membantu anak-anak tunarungu mengingat pelajaran agama Islam di sekolah. Pada bacaan shalat, anak-anak tunarungu menjawab bahwa bahasa isyarat dapat membantu dalam membaca bacaan shalat. Pengaplikasian bacaan isyarat tidak hanya di sekolah, melainkan pada saat di rumah.

\section{Perhatian Anak-anak Tunarungu Terhadap Bahasa Isyarat Dalam Memahami Bacaan Shalat}

Indikator pertama meliputi lima soal yang lebih menekankan pada aspek perhatian anak-anak tunarungu terhadap bahasa isyarat dalam memahami bacaan shalat dari segi penyampaian bahasa isyarat oleh guru yang dirasakan oleh siswa siswi tunarungu karena sebagian besar guru dapat mendengar.

Perhatian erat hubungannya dengan kesadaran jiwa terhadap suatu objek yang direaksi pada suatu waktu. Perhatian juga dapat timbul dari adanya pemusatan kesadaran kita terhadap sesuatu. Dalam hal ini, perhatian dapat diartikan keaktifan jiwa yang diarahkan kepada sesuatu objek, baik yang ada di luar maupun di dalam dirinya (Ahmadi, 2003:145).

Perhatian yang timbul dengan sendirinya oleh karena tertarik pada sesuatu dan tidak terdorong kemauan, ini disebut dengan perhatian spontan. Untuk perhatian disengaja, perhatian yang didorong oleh kemauan karena adanya tujuan tertentu. Perhatian tetap terhadap sesuatu, disebut perhatian statis. Sebaliknya perhatian yang mudah berubah-ubah dan mudah bergerak disebut perhatian dinamis. 
"Perhatian terjadi bila kita mengonsentrasikan diri pada salah satu alat indera kita, dan mengenyampingkan masukan-masukan melalui alat indera yang lain.” (Rakhmat ,2012:51)

Pada perhatian luas, orang yang mempunyai perhatian. Perhatian fiktif (melekat), yaitu perhatian yang mudah dipusatkan pada suatu hal dan boleh dikatakan bahwa perhatiannya dapat melekat pada objeknya. Perhatian fluktuatif atau bergelombang, umumnya memperhatikan macam-macam hal sekaligus.

Pembawaan: pembawaan tertentu berhubungan dengan objek yang direaksi, sedikit banyak akan timbul perhatian dengan objek tertentu.Latihan dan kebiasaan: Hasil latihan dan kebiasaan dapat menimbulkan perhatian terhadap bidang tertentu.Kebutuhan: kebutuhan memungkinkan timbul perhatian terhadap suatu objek tertentu. Keadaan jasmani: keadaan tubuh mempengaruhi perhatian kita terhadap suatu objek.Suasana jiwa: keadaan perasaan serta batin mempengaruhi perhatian kita terhadap sesuatu. (Ahmadi, 2003:145)

Setelah menghitung perolehan respon anak-anak tunarungu, kemudian hasil data yang dihitung akan dimasukkan ke dalam tabel tabulasi sebagai berikut:

Tabel 3. Pernyataan Pertama pada Indikator Perhatian

\begin{tabular}{|c|c|c|c|c|}
\hline Alternatif Jawaban & Bobot Nilai (x) & Frekuensi (F) & FX & Jumlah \\
\hline Bagus & 3 & 9 orang & 27 & $90 \%$ \\
\hline Kurang Bagus & 2 & 1 orang & 2 & $10 \%$ \\
\hline Tidak Bagus & 1 & 0 & 0 & $0 \%$ \\
\hline \multicolumn{2}{|c|}{ Jumlah } & 10 orang & 29 & $100 \%$ \\
\hline
\end{tabular}

Sumber data: Hasil pengolahan angket 23 Juli 2019

Dari tabel di atas, terdapat 90\% responden menyatakan Bagus. Bagus dalam angket ini sama dengan setuju, dikarenakan anak-anak tunarungu tidak terlalu paham maksud dari setuju. Untuk itu penulis mengganti pilihan jawaban sesuai dengan konsultasi yang sudah dilakukan penulis dengan guru yang mengajar di SLB Negeri Cileunyi. Dalam hal ini $90 \%$ responden menyatakan bagus pada saat guru mengajarkan pelajaran menggunakan bahasa isyarat. Artinya hampir seluruh anak-anak tunarungu merasa jelas dengan penjelasan yang diberikan guru saat menerangkan pelajaran menggunakan bahasa isyarat. Kemudian $10 \%$ responden menyatakan kurang bagus pada saat guru menerangkan pelajaran menggunakan bahasa isyarat. Artinya sebagian kecil anak- 
anak tunarungu kurang begitu suka saat guru menerangkan pelajaran menggunakan bahasa isyarat.

Tabel 7. Pernyataan Kelima pada Indikator Perhatian

\begin{tabular}{|c|c|c|c|c|}
\hline Alternatif Jawaban & Bobot Nilai (x) & Frekuensi (F) & FX & Jumlah \\
\hline Bagus & 3 & 7 orang & 21 & $70 \%$ \\
\hline Kurang Bagus & 2 & 3 orang & 6 & $30 \%$ \\
\hline Tidak Bagus & 1 & 0 & 0 & $0 \%$ \\
\hline \multicolumn{2}{|c|}{ Jumlah } & 10 orang & 27 & $100 \%$ \\
\hline
\end{tabular}

Sumber data: Hasil pengolahan angket 23 Juli 2019

Dari perhitungan tabel di atas, sebagian besar anak-anak tunarungu sebanyak $70 \%$ dapat mengikuti bacaan shalat menggunakan bahasa isyarat dengan baik. Artinya kebanyakan dari anak-anak tunarungu pada saat belajar bacaan sholat yang diajarkan menggunakan bahasa isyarat, dapat mengikutinya dengan baik. Kemudian sebagian kecil atau 30\% anak-anak tunarungu kurang dapat mengikuti bacaan shalat menggunakan bahasa isyarat.

\section{Pemahaman Anak-anak Tunarungu Terhadap Bahasa Isyarat dalam Memahami Bacaan Shalat}

Indikator kedua meliputi lima soal yang lebih menekankan pada aspek pemahaman anak-anak tunarungu terhadap bahasa isyarat dalam memahami bacaan shalat, dari segi pengetahuan anak-anak tunarungu tentang bahasa isyarat serta pemahaman anak-anak tunarungu tentang pelajaran sekolah, pelajaran agama Islam sampai pada yang menjadi pokok bahasan yaitu bacaan shalat.

Pemahaman membentuk pribadi dan cara berpikir agar lebih mudah ketika kita bertemu oranglain (komunikan) yang mempunyai sikap serta prilaku yang matang (dewasa). Pemahaman sebagai pengaruh disebabkan adanya respon yang memberikan pengetahun berkaitan dengan batiniyah dan psikis sendiri, hingga dapat dijadikan pembelajaran dalam proses pembentukan watak dan pribadi seseorang (Astriani, 2017:47)

"Suharsimi menyatakan bahwa pemahaman (comprehension) adalah bagaimana seorang mempertahankan, membedakan, menduga (estimates), menerangkan, memperluas, menyimpulkan, menggeneralisasikan, memberikan contoh, menuliskan kembali, dan memperkirakan." 
(Suharsimi, 2009:118)

Walaupun bahasa isyarat merupakan bahasa yang digunakan sehai-hari untuk berkomunikasi dengan teman-teman, guru serta keluarga. Namun tidak semua anak dapat langsung memahami bahasa isyarat itu sendiri. Apalagi dalam bacaan shalat yang biasa disampaikan oleh bahasa lisan. Ini menjadi salah satu tantangan dalam menyampaikan seluruh bacaan shalat mulai dari niat shalat hingga salam menggunakan bahasa isyarat.

"Proses menangkap stimuli melalui panca indera yang baik secara langsung maupun tidak langsung dengan cara cepat atau lambat merupakan poses dari pemahaman." (Astriani, 2017:47)

Pada soal pertama diberikan pernyataan "Saya bisa paham bahasa isyarat dengan baik“. Pernyataan yang digunakan oleh penulis sudah di konsultasikan terlebih dahulu dengan guru yang mengajar, dan menggunakan bahasa yang lebih ringkas serta dapat dimengerti oleh anak-anak tunarungu, sehingga pada saat menjawab angket yang diberikan sebagian besar tidak kebingungan dan memahami maksud pernyataan yang ada dalam angket. Dari pernyataan tersebut di peroleh jawaban sebagai berikut:

Tabel 8. Pada Pernyataan Pertama pada Indikator Pemahaman

\begin{tabular}{|c|c|c|c|c|}
\hline Alternatif Jawaban & Bobot Nilai (x) & Frekuensi (F) & FX & Jumlah \\
\hline Bagus & 3 & 7 orang & 21 & $70 \%$ \\
\hline Kurang Bagus & 2 & 3 orang & 6 & $30 \%$ \\
\hline Tidak Bagus & 1 & 0 & 0 & $0 \%$ \\
\hline \multicolumn{2}{|c|}{ Jumlah } & 10 orang & 27 & $100 \%$ \\
\hline
\end{tabular}

Sumber data: Hasil pengolahan angket 23 Juli 2019

- Dari perhitungan tabel di atas, sebagian besar responden atau anak-anak tunarungu sebanyak 70\% memilih Bagus. Ini berarti anak-anak tunarungu memahami bahasa isyarat. Kemudian 30\% dari responden atau anak-anak tunarungu memilih Kurang Bagus. Interpretasi data yang diperoleh $\bar{x}=2,7$, pada rentang 2,6-3,5 pada tingkat tinggi.

Tabel 10. Pernyataan Ketiga pada Indikator Pemahaman

\begin{tabular}{lllll}
\hline Alternatif Jawaban & Bobot Nilai (x) & Frekuensi (F) & FX & Jumlah \\
\hline
\end{tabular}

Tabligh: Jurnal Komunikasi dan Penyiaran Islam Vol. 5 No. 2 (2020) 112-129 


\begin{tabular}{|c|c|c|c|c|}
\hline Bagus & 3 & 5 orang & 15 & $50 \%$ \\
\hline Kurang Bagus & 2 & 5 orang & 10 & $50 \%$ \\
\hline Tidak Bagus & 1 & 0 & 0 & $0 \%$ \\
\hline \multicolumn{2}{|c|}{ Jumlah } & 10 orang & 25 & $100 \%$ \\
\hline
\end{tabular}

Sumber data: Hasil pengolahan angket 23 Juli 2019

Dari perhitungan tabel di atas, terdapat 50\% dari responden yaitu anakanak tunarungu memilih jawaban Bagus. Kemudian 50\% lainnya memilih jawaban Kurang Bagus. Ini dapat berarti setengah dari responden atau anak-anak tunarungu merasa kurang memahami pelajaran agama Islam. Interpretasi data yang diperoleh yaitu $\bar{x}=2,5$ berada pada rentang 1,6-2,5 pada tingkat sedang.

Tabel 11. Pernyataan Keempat pada Indikator Pemahaman

\begin{tabular}{|c|c|c|c|c|}
\hline Alternatif Jawaban & Bobot Nilai (x) & Frekuensi (F) & FX & Jumlah \\
\hline Bagus & 3 & 7 orang & 21 & $70 \%$ \\
\hline Kurang Bagus & 2 & 3 orang & 6 & $30 \%$ \\
\hline Tidak Bagus & 1 & 0 & 0 & $0 \%$ \\
\hline \multicolumn{2}{|c|}{ Jumlah } & 10 orang & 27 & $100 \%$ \\
\hline
\end{tabular}

Sumber data: Hasil pengolahan angket 23 Juli 2019

Dari perhitungan tabel di atas, 70\% responden yaitu anak-anak tunarungu di SLB Negeri Cileunyi memilih jawaban Bagus. Guru yang mengajar, biasanya menyampaikan materi bacaan shalat menggunakan gerak bibir serta intonasi yang jelas, agar gerak bibir dari guru dapat dipahami oleh anak-anak tunarungu. Interpretasi data yang diperoleh $\bar{x}=2,7$ berada pada rentang 2,6-3,5 pada tingkat tinggi.

Tabel 12. Pernyataan Kelima pada Indikator Pemahaman

\begin{tabular}{ccccc}
\hline Alternatif Jawaban & Bobot Nilai (x) & Frekuensi(F) & FX & Jumlah \\
\hline Bagus & 3 & 5 orang & 15 & $50 \%$
\end{tabular}


Kurang Bagus 2

Tidak Bagus

2

1

$$
5 \text { orang }
$$

0
10

0
$50 \%$

$0 \%$

Jumlah

10 orang

25

$100 \%$

Sumber data: Hasil pengolahan angket 23 Juli 2019

Dari perhitungan tabel di atas, sebanyak 50\% dari responden memilih jawaban Bagus. Kemudian, setengah lagi dari responden memilih jawaban Kurang Bagus. Ini berarti, 50\% dari responden kurang memahami bacaan shalat mulai dari niat shalat hingga salam.

\section{Penerimaan Anak-anak Tunarungu Terhadap Bahasa Isyarat Dalam Memahami Bacaan Shalat}

Indikator ketiga meliputi lima soal yang lebih menekankan pada aspek penerimaan anak-anak tunarungu terhadap bahasa isyarat dalam memahami bacaan sholat. Dalam indikator ketiga ini akan membahas mengenai penerimaan sampai pada aplikasi bacaan shalat.

Penerimaan dipengaruhi suasana perasaan seseorang. Perasaan merupakan salah satu faktor yang harus diperhatikan. Perasaan dapat dikatakan juga sebagai suasana hati. Suasana hati merupakan kondisi saat perasaan yang berkesinambungan dengan timbulnya rasa senang atau tidak senang yang tidak jelas, menyebar dan kemana-mana. (Astriani, 2017:48)

"Penerimaan merupakan kemampuan penghubung dengan oranglain tanpa menilai dan tanpa berusaha mengendalikan. Penerimaan juga sikap yang melihat perilaku terhadap pelaku lainnya". (Rakhmat, 2012:129)

Pengaplikasian yang dimaksud yaitu dalam praktek shalat di sekolah maupun dirumah. Dalam aspek perhatian dan pemahaman, telah dibahas sebelumnya, mayoritas atau rata-rata responden dapat menggunakan bahasa isyarat dengan baik, mengerti bahasa isyarat dengan baik

Adapun memberikan respon untuk meminta penjelasan juga merupakan indikasi adanya penerimaan pesan. Respon tersebut menunjukkan tanggapan yang baik kepada pesan. Tanpa adanya penerimaan maka akan sulit memberikan respon berupa pernyataan atau pernyataan. (Rakhmat,2012:129) 
Tabel 16. Pernyataan Keempat pada Indikator Penerimaan

\begin{tabular}{|c|c|c|c|c|}
\hline Alternatif Jawaban & Bobot Nilai (x) & Frekuensi (F) & FX & Jumlah \\
\hline Bagus & 3 & 5 orang & 15 & $50 \%$ \\
\hline Kurang Bagus & 2 & 5 orang & 10 & $50 \%$ \\
\hline Tidak Bagus & 1 & 0 & 0 & $0 \%$ \\
\hline \multicolumn{2}{|c|}{ Jumlah } & 10 orang & 25 & $100 \%$ \\
\hline
\end{tabular}

Sumber data: Hasil pengolahan angket 23 Juli 2019

Dari perhitungan di atas, hasil yang didapatkan sama. Dari sepuluh responden, lima orang menjawab Bagus dan lima orang lainnya menjawab Kurang Bagus.

Tabel 17. Pernyataan Kelima pada Indikator Penerimaan

\begin{tabular}{|c|c|c|c|c|}
\hline Alternatif Jawaban & Bobot Nilai (x) & Frekuensi $(\mathrm{F})$ & FX & Jumlah \\
\hline Bagus & 3 & 10 orang & 30 & $100 \%$ \\
\hline Kurang Bagus & 2 & 0 & 0 & $0 \%$ \\
\hline Tidak Bagus & 1 & 0 & 0 & $0 \%$ \\
\hline \multicolumn{2}{|c|}{ Jumlah } & 10 orang & 30 & $100 \%$ \\
\hline
\end{tabular}

Sumber data: Hasil pengolahan angket 23 Juli 2019

Dari perhitungan di atas, semua responden menjawab Bagus. Artinya pada pengaplikasian bacaan shalat di rumah, anak-anak dapat mengikutinya. Bacaan shalat tidak hanya dipelajari di sekolah tetapi juga di rumah. Interpretasi data yang diperoleh yaitu $\bar{x}=3$ berada pada rentang 2,6-3,5 pada tingkatan tinggi.

\section{PENUTUP}

Berdasarkan pengolahan data yang dilakukan oleh peneliti, maka penelitian kali ini yang berjudul " Respon Anak-anak Tunarungu Terhadap Bahasa Isyarat Dalam Memahami Bacaan Shalat (Studi Deskriptif di SLB Negeri Cileunyi Jln. Pandawangi Cibiru III Cileunyi Kabupaten Bandung)" dapat ditarik kesimpulan bahwa bahasa isyarat yang digunakan dalam mengajarkan bacaan shalat memiliki hasil yang cukup efektif dengan hasil pada indikator perhatian dengan presentase rata-rata sebesar $66 \%$. Pada indikator pemahaman hasil presentase 
rata-rata sebesar $64 \%$, dan pada indikator penerimaan dengan hasil presentase rata-rata sebesar $70 \%$.

Pada aspek perhatian memiliki presentase rata-rata sebesar 66\% dimana nilai persen tersebut berarti sebagian besar anak-anak tunarungu dalam perhatiannya terhadap bahasa isyarat baik. Dalam perhatian terhadap pelajaran agama Islam serta pada materi bacaan shalat pun dikategorikan baik

Pada aspek pemahaman memiliki presentase rata-rata sebesar 64\% dimana nilai persen tersebut dapat berarti sebagian besar anak-anak tunarungu dalam pemahaman mengenai bahasa isyarat dapat dikategorikan baik. Dalam pemahaman terhadap pelajaran agama serta bacaan shalat yang diajarkan di sekolah dikategorikan baik.

Pada aspek penerimaan memiliki presentase rata-rata sebesar 70\% dimana nilai persen tersebut berarti sebagian besar anak-anak tunarungu dalam penerimaan terhaap bahasa isyarat cukup baik. Bahasa isyarat digunakan seharihari unruk berkomunikasi dengan teman-teman mereka. Dapat berarti bahasa isyarat sampai pada pengaplikasiaannya dilakukan dengan baik. Dalam pelajaran agama Islam dan bacaan shalat, bahasa isyarat dapat memudahkan dalam proses belajar. Pengaplikasian bacaan shalat tidak hanya saat di sekolah, tetapi juga pada saat di rumah.

Ketiga hasil tersebut pada hasil penafsiran penelitian memiliki penafsiran Sebagian Besar. Sebagian besar responden yang merupakan anak-anak tunarungu menggunakan bahasa isyarat dalam berkomunikasi sehari-hari dengan teman, pada mata pelajaran pun mereka menggunakan bahasa isyarat SIBI (Sistem isyarat Bahasa Indonesia) yang biasanya digunakan di sekolah, termasuk pada mata pelajaran agama Islam dan materi bacaan shalat.

Saran untuk penelitian penelitian selanjutnya; untuk penulisan karya tulis ilmiah ini, masih penuh dengan keterbatasan untuk itu penulis mohon kritik dan masukan yang dapat membangun agar karya tulis ini dapat lebih baik lagi kedepannya. Penulis bertujuan agar karya tulis ini dapat bermanfaat bagi sesama. Penulis juga bertujuan agar kita lebih memperhatikan sesama, walaupun memiliki keterbatasan dalam berkomunikasi. Setiap orang memiliki hak yang sama dalam memperoleh pengetahuan, oleh karena itu tidak perlu membeda-bedakan sesama. Dukung dan bimbinglah teman-teman kita yang memiliki keterbatasan khusus.

\section{DAFTAR PUSTAKA}


Ahmadi, A. (2003). Psikologi Umum. Bandung: Pustaka Setia.

Astriani, G. (2017). Respon Mad'u Terbadap Media Dakwah Nonverbal (Analisis

Deskriptif Respon Pembeli Terhadap Media Dakwah Nonverbal di Waroeng Steak and Shake Jatinagor). Jurusan Komunikasi dan Penyiaran Islam Universitas Islam Negeri Sunan Gunung Djati Bandung.

AS, Enjang dan Aliyudin. (2009). Dasar-Dasar Ilmu Dakwah. Bandung: Widya Padjadjaran.

Febrina, H.R. (2015). Penggunaan Bahasa Isyarat Sebagai Komunikasi (Studi Efektivitas Komunikasi Non Verbal Dan Non Vokal Pada Siaran Berita Turi Nasional Terhadap Penyandang Tunarungu Slb Pgri Minggir, Sleman, Yogyakarta). Program Studi Ilmu Komunikasi Universitas Islam Negeri Sunan Kalijaga Yogyakarta.

Gunawan, A.S.A. (2013). Pembelajaran Bahasa Isyarat dengan Kinect dan Metode Dynamic Time Warping. Mathematics \& Statistics Department, School of Computer Science, Binus University Jl. K. H. Syahdan No. 9, Palmerah, Jakarta Barat 11480, 13(02).

Maulia, N.(2017). Pengaruh Penggunaan Sistem Isyarat Bahasa Indonesia (SIBI) Terbadap Pemahaman Informasi Siswa Penyandang Tunarungu di SLB-PKK Provinsi Lampung. Jurusan Ilmu Komunikasi Universitas Lampung, 1(1).

Mubasyaroh. (2017). Strategi Dakwah Persuasif Dalam Mengubah Perilaku Masyarakat. Ilmu Dakwah: Academic Journal for Homiletic Studies,11(2), 311 324.

Mulyana, D. (2014). Ilmu Komunikasi Suatu Pengantar.Bandung: Remaja Rosdakarya

Rakhmat, J. (2012). Psikologi Komunikasi. Bandung: Remaja Rosdakarya.

Sihabudin, Dede. (2019). Komunikasi Pada Masyarakat Adat Kampung Dukuh Garut. Anida (Aktualisasi Nuansa Ilmu Dakwah), 19(9), 63-88.

Suharsimi, A. Dasar - Dasar Evaluasi Pendidikan (edisi revisi). (Jakarta: Bumi Aksara, 2009), Cetakan 9. 118.

Winaldi, I. dan Agus Setyawan. (2018). Aplikasi Pengenalan Bahasa Isyarat Untuk Penyandang Tunarungu Berbasis Android (Studi Kasus: SLB Madina Serang). Program Studi Sistem Informasi Fakultas Teknologi Informasi Universitas Serang Raya, 5(2).

Parwiyuliati, W. (2017). Respon Jamaah Masjid Abu Bakar Ash-Shidiq Terhadap Gaya Busana Ustadz. Evie Effendie Dalam Berdakwah (Studi Deskriptif pada Jamaah Majid Abu Bakar Ash-Shidiq Bumi Panyawangan Real Estate Cileunyi Kab. Bandung),Jurusan Komunikasi dan Penyiaran Islam, Fakultas Dakwah dan 
Komunikasi, Universitas Islam Negeri Sunan Gunung Djati Bandung. Terjemah Al-Quran Departemen Agama RI Tahun 2007 